\title{
Communicative Language Teaching: Changing Students' Speaking Skill
}

\author{
Juni Bayu Saputra, S.Pd., M.Pd
}

The Head of English Education Study Program at the Higher School of Teacher Training and Education of Tunas Palapa Lampung Tengah junibayu.albana@gmail.com

\section{Wargianto, S.Pd.SI, M.Pd}

The Deputy of Academic Department at the Higher School of Teacher Training and Education of Tunas Palapa Lampung Tengah

\begin{abstract}
This article points out the results of the study attempting to solve the speaking problem faced by students in one of the Higher School of Teacher Training and Education (STKIP) in Central Lampung. For the purpose of the topic, 30 fellow students were selected as the subject. Research method was Classroom Action Research with Kemmis and Taggart model. It was conducted for about four cycles. According to the results of speaking test, findings showed that using Communicative Language Teaching (CLT) had positive meaningful effect on improving students' speaking skill. To sum up, CLT is an effective method to teach speaking to the subject.
\end{abstract}

Key term: Communicative Language Teaching, Speaking Skill. 


\section{Introduction}

A large percentage of the world's language learners study English in order to develop proficiency in speaking. It means, speaking as one of four language skills should be mastered by students or people if they want to interact with people around the world and get success later in their life (Richard \& Renandya, 2002, p. 201). Speaking is one of the four language skills that should be developed beside the other three language skills. According to Spratt et.al (2005) speaking is a productive skill like writing, it involves using speech to express meaning to other people. We can develop learners' speaking skills by focusing regularly on particular aspect of speaking, e.g. fluency, pronunciation, grammatical accuracy or body language (p. 34).

Furthermore, speaking is one way to communicate with ideas and though a message orally. To enable students to communicate, we need to apply the language in real communication. According to Rickheit \& Strohner (2008) speaking is speech or utterances with the purpose of having intention to be recognized by speaker and the receiver processes the statements in order to recognize their intentions ( $\mathrm{p}$. 207).

Speaking, as one of the English language skill has some aspects. According to Spratt, et.al (2005) there are four aspects of speaking, they are: fluency, pronunciation, grammatical accuracy, and body language. Furthermore, Spratt, et.al explains that fluency is speaking at a normal speed, without hesitation, repetition or self- correction, and with smooth use of connected speech. Meanwhile, accuracy in speaking is the use of correct grammar, vocabulary and pronunciation (p.35).

According to Jones (2007) fluency means using simple words to express meaning, even though longer words might be more descriptive. Also, fluency means speaking slowly and clearly, not speaking fast and unclearly. Fluency depends on knowing more vocabulary and on confidence - and on not worrying about losing face by making mistakes. Another component of fluency is being able to articulate easily and comprehensively. Meanwhile, Accuracy means not making too many mistakes. We certainly want our students to become more fluent, but we also want them to become more accurate. An overconfident, inaccurate speaker can be an irritating companion, though preferable to a silent one ( $\mathrm{p}$. $18)$.

In addition, Crystal, (1977); Bryne, (1986); Nation, (1999) in Lan (1994) state that fluency may be defined as the ability to get across communicative intent without too much hesitation and too many pauses to cause barriers or a breakdown in communication. Meanwhile, accuracy refers to the use of correct forms where utterances do not contain errors affecting the phonological, syntactic, semantic or discourse features of a language.

From above description, it is known that accuracy and fluency are closely related, which leads us to the notion that accuracy as well as fluency is necessary for successful communication. Fluency and accuracy are two factors which can determine the success of English language students in the future and 
the most essential linguistic behavior in classroom teaching.

Thus, Brown and Yule (1999) state that speaking is depending on the complexity of the information to be communicated; however, the speaker sometimes finds it difficult to clarify what they want to say (p. 14). Kayi (2006) says that teaching speaking is a very important part of second language learning. The ability to communicate in a second language clearly and efficiently contributes to the success of the learners in school and success later in their life. Thus, it is essential that language teacher pay great attention to the teaching of speaking (p. 1).

From the above discussion, it shows that mastering speaking skill is very important for the students in order to make the students are able to communicate in English with other people from other countries easily. Especially if they want to go abroad, it is an obligation for them to be able to communicate in English since English is applied as the first international language in countries all over the world. Moreover, Indonesia is now being one of the ASEAN free trade Countries which means that if they cannot master speaking well, they will never be able to participate with. In addition, mastering English especially speaking for the fellow students of STKIP level is very important and even a must. It is because they want to be a teacher who must speak at least bilingual language (Bahasa and English); otherwise, their job might be replaced by those foreigners from another ASEAN free trade Countries member.

But in fact, students face a lot of problems in mastering the speaking skill. The lack of practice of the language both inside and outside the classroom is the main cause of the students' failure in mastering speaking skill. Besides, the very limited time is also considered to support the failure of the students' speaking skill since the English lesson at the higher school is usually held just for two hours per week. Higher schools apply the integrated teaching of English consisting of listening, speaking, reading, and writing. Consequently, the proportion of teaching speaking is very limited because it is integrated with the other three language skills. Since the time for teaching speaking is very limited, English lecturer are expected to be able to make use the available time more effectively and efficiently by applying a certain strategy that can involve all students more actively in joining the speaking class.

Based on the researcher's teaching experience in his classroom, he found many problems related to the teaching of speaking. Most of the students were not really motivated in speaking task. Some of them really wanted to express their ideas or feeling about the material being taught, but they do not know how to express their idea. This was due their limited vocabulary and the classroom encouragement (friends and different cultural background). Some of them knew how to construct sentences but they were reluctant to speak. They were afraid of making mistakes in pronouncing the words or English grammar. Besides, they were afraid of being laughed at by other students, so they just keep silent and bore their ideas and feeling in their mind. Harmer (2007) states that students are often reluctant to speak because they are shy and are not predisposed 
to expressing themselves in front of other people, especially when they are being asked to give personal information or opinion (p. 345).

Burns and Joyce (1999) state that there are three factors that may cause students to be reluctant to participate in classroom task which involve speaking. First, cultural factor, such as belief that learning involves listening to the teacher and not actively speaking up in the class and a belief that language learning is based primarily on reading and writing from a textbook and completing written exercises. Second, linguistic factor, such as difficulties in transferring from the learners' first language to the sound, rhythm, and stress pattern of English, difficulties with the native speakers pronunciation of the teacher, a lack of understanding of common grammatical patterns in English (e.g. English tenses) and how may be these different from their own language, lack of familiarity with the cultural or social language knowledge required to process meaning. Third, range of psychological and affective factors including culture shock, previous negative social or political experiences, lacks of motivation, anxiety, and shyness in class (p. 134). In addition, Chastain in Nambiar (1985) states that learners are reluctant to participate in oral activities because of the following: (1) speaking practice is more difficult than sitting back and listening to the teacher or wandering off into some dream world; (2) many students feel uncomfortable in their first attempts at speech in the second language; (3) many students are selfconscious and don't like to make mistakes or to appear stupid in front of their peers; and (4) they are afraid of failure, laughter and ridicule ( $\mathrm{p}$. 45).

Furthermore, Lightbown \& Spada (2001) state classroom tasks and patterns of interactions which are far from the students' level of competence do not promote their communicative competence. When they find that such kinds of task and patterns of interactions are difficult, then they tend to discourage to have speaking practice.

The problem coming from the students as stated by Lucantoni (2002) is when students think that they are based on what they say. They then prefer keeping silent to speaking language (p. 48). In addition, Lucantoni (2002) proposes suggestions to solve the problems. First, provide students with the functional exponents they need in order to carry out pair work and roleplay activities, and demonstrate exactly what they have to do. Then, put them in situation where they have to speak in English in order to complete a task. Secondly, always encourage - do not allow students to become discourage when they make mistakes. They have to understand that making mistakes is part of the learning process (p. 6).

Based on the discussion above, then the researcher try to make use of Communicative Teaching Learning (CLT) to solve the existing problem. It is because during learning process of CLT, students' are hoped to communicate orally and conquer all components of communicative competence and teacher is being motivator, assessor, facilitator, and corrector during students' discussion or speaking in front of the class. In addition, the teacher also should make their lesson interesting so the 
students don't fall asleep during learning English (Harmer, 1998, p. 1). Learning activities in CLT focuses on real oral communication with variety of language without too focus on form of grammatical patterns if distinguished with noncommunicative activities which only focus on how to construct the sentences that based on terms of grammatical during learning process of English (Harmer, 1998, p. 85).

CLT itself started in the late 1960s and continues to evolve. It is not actually a method but an approach to teaching based on the view that learning a language means learning how to communicate effectively in the world outside the classroom. It developed mainly as a reaction to the limitations of previous methods which put little, if any, emphasis on the ability to communicate or interact. It was also influenced by developments in the way the language was described taking into account the communicative function of language, i.e. that we use language to do things like suggest, invite, agree, request, criticize, predict, and so on (Richards and Rodgers, 2001, p. 153).

Communicative approach in language teaching starts from a theory of language as communication. The goal of language teaching is to develop communicative competence (Richard and Rodger, 1999, p. 69).

CLT appeared at a time when British language teaching was ready for a paradigm shift. Situational Language Teaching was no longer felt to reflect a methodology appropriate for the seventies and beyond. CLT appealed to those who sought a more humanistic approach to teaching, one in which the interactive processes of communication received priority. The rapid adoption and implementation of the communicative approach also resulted from the fact that it quickly assumed the status of orthodoxy in British language teaching circles, receiving the sanction and support of leading British applied linguists, language specialists, publishers, as well as institutions, such as the British Council (Richards, 1985).

CLT is the name which was given to a set of beliefs which included not only a re-examination of what aspect of language to teach, but also in a shift in emphasis in how to teach. The "what to teach" aspect of the communicative approach stressed the significance of language function rather than focusing solely on grammar and vocabulary. A guiding principle was to train students to use these language forms appropriately in variety of context and for a variety of purposes. The "how to teach aspect" of communicative approach is closely related to the idea that language learning will take care of its self and that plentiful exposure to language in use and plenty of opportunities to use it are vitally important for students' development and skill (Harmer, 1998, p. 84).

CLT can be understood as a set of principles about the goals of language teaching, how learners learn a language, the kinds of classroom activities that best facilitate learning, and the roles of teachers and learners in the classroom (Richards, 2006, p. 3).

CLT aims to make communicative competence as the goal of language teaching and to develop techniques and procedures 
for teaching language skills that are based on interdependent aspects of language and communication. Communicative competence includes grammatical competence, sociolinguistic, and strategies. Communicative language abilities include knowledge or competence and proficiency in the application of these competencies in the communicative use of language, contextual, and appropriate. Littlewood (1981) states, "One of the most characteristic features of CLT is that it pays systematic attention to functional as well as structural aspects of language." For others, it means using procedures where learners work in pairs or groups employing available language resources in problem-solving tasks (p. 1).

In relation with CLT to teach speaking, research has shown that CLT can be used to improve students' speaking skill (Efrizal, 2012 and Wenjie, 2009).

Thus, based on its benefits for English learning and other good values of the use of CLT, in order to enrich the research, this study is then proposed to improve the speaking skill for the fellow students in one of STKIP in Central Lampung.

\section{Research Methodology}

This research employed Classroom Action Research (CAR) design. The purpose of conducting CAR was to solve the problems happened in the classroom that is faced by the students. This was in line with the description on the background of study. One of the problems faced in the classroom was learning achievement in speaking skill. Hence, by doing Classroom Action Research (CAR), hopefully the researcher got the improvement of learning quality in the classroom as learning achievement in speaking skill. In line with this, Latief (2008) argued that Classroom Action Research is the research design that is constructed for improving the quality of learning in the classroom (p. 2).

In Classroom Action Research, initially a researcher identifies problems which happens in teaching learning process, then sets the plan, design a way to solve problems, and implements the plan. Therefore, the researcher focuses on a particular classroom aiming at finding the solution for the problems takes place there.

The research was administered at STKIP Tunas Palapa Lampung Tengah. The school was chosen as the setting under some consideration. Firstly, the researcher is one of the English lecturers at STKIP Tunas Palapa Lampung Tengah. Secondly, the researcher is inspired to solve students' problems in speaking skill by using CLT. The subject of this research was Ia students of the first semester which consist of 30 students in the year academic of 2014/2015.

In conducting the research, the researcher is helped by the Deputy who responsible for Academic Department of STKIP Tunas Palapa Lampung Tengah as a collaborator. As Kemmis and Mc Taggart (1988) assert that action research is collaborative. It means that the researcher works together with his colleague from the beginning until the end of the research activities.

The design of the present study follows the procedure of Action Research proposed by Kemmis and Taggart which stated that action 
research involves self-reflective spirals of planning, acting, observing, and reflecting. They also point out that planning involves the determination of the question that need answering and the strategy to be used in answering it. During the acting stage, the practitioner tried out the strategy. The observation stage included recording data on the results of the strategy. The reflection stage refers to data analysis. It means that the researcher shows the result of the action done in each action and replanning of the next cycles is done do if the action of each cycle is unsuccessful or the result of the teaching and learning process has not met the predetermined criteria of success yet. In opposite, when the action done have met the proposed criteria of success, another cycle is not carried out.

In collecting the data above, the researcher utilized some instruments such as observation checklist, field notes, and speaking skill tests. Observation checklist was used to obtain the data about students' activities in teaching speaking by using CLT during activities in the classroom. The observation checklist is focused on how the students responded to the teacher's questions in activating students' background knowledge, how they responded to the teacher's explanation, and how they engaged in the whilst speaking activity whether active or passive.

Field notes would be used to jot down any data that were not covered in the observation checklist. Thus, the field notes might utilize to identify some aspects reflected in teaching and learning process, such as appropriate topic of speaking instruction, things to be improved, and students' interaction among the peers that are beyond the coverage of the observation checklist.

Speaking test was in the form of describing test which is used for describing the students' speaking skill, the students' mean score, and the individual score after implementing the CLT. This test was administered at the end of the cycle. The speaking test was in monologue form about "describing thing around us". The inter-rater scoring system is used during the speaking test. In this test, there are two testers who judge the students' speaking skill during their performance.

\section{Discussion of the Findings}

The result of the test focused mainly on the students' individual score, it indicated the ability of each student in speaking skill. After analyzing the result of speaking test in Cycle 1 by standing on the criteria of success, that improvement will happen if the $75 \%$ students' get score increased up to 70 , then the researcher classify whether or not the result of the test qualified to the criteria of success. If not, the researcher must continue to the second cycles and more until the criteria of success was fulfilled.

\section{a. Discussion of the Findings on the Students' Speaking Performance at Cycle 1 \\ Based on the data from} students' speaking performance, the researcher had the data about the students' speaking performance. In analyzing the students' speaking performance, the researcher used analytic scoring rubric. The scoring rubric was adapted from Ur (1996, p. 135). The students' scores of speaking performance are presented 
in the Table 3.1 as follows.

Table 3.1 The Students' Score of Speaking Performance

\begin{tabular}{|c|c|c|c|}
\hline No & $\begin{array}{l}\text { Score } \\
\text { Range }\end{array}$ & $\begin{array}{c}\text { Number } \\
\text { of } \\
\text { Students }\end{array}$ & $\begin{array}{c}\text { Percentag } \\
\text { e }\end{array}$ \\
\hline 1 & $80-100$ & - & $0 \%$ \\
\hline 2 & $75-79$ & 11 & $31 \%$ \\
\hline 3 & $70-74$ & 11 & $31 \%$ \\
\hline 4 & $65-69$ & 8 & $23 \%$ \\
\hline 5 & $<64$ & 5 & $14 \%$ \\
\hline \multicolumn{2}{|c|}{ Total } & 35 & $100 \%$ \\
\hline
\end{tabular}

Based on the data above, it can be seen that there was no one who achieved score in the range of $80-$ 100. There were eleven students (31\% of the students) achieved the score range in the range of $75-79$. There were eleven students $(31 \%$ of the students) who achieved the score range of $70-74$. There were eight students (23\% of the students) who achieved the score in the range $65-$ 69. Meanwhile, there were five students (14\% of the students) who achieved the score in the range of $<69$.

From the analysis of the students' speaking performance, it was found that they still have difficulties for both aspects of speaking being observed namely fluency and accuracy.

In the aspect of fluency, five students (14\% of 35 students) were in level of "little communication". There were fourteen students $(40 \%$ of 35 students) who were "very hesitant and have brief utterances, sometimes difficult to understand". There were eleven students ( $31 \%$ of 35 students) who "got ideas across, but hesitantly and briefly". Then, there were 5 students (14\% of 35 students) were "effective communication in short turn". And no student was in the level of "easy and effective communication".

In terms of accuracy, seven students $(20 \%$ of 35 students) produced "little language". There were seven students (20\% of 35 students) was "poor vocabulary, mistakes in basic grammar, may have very strong foreign accent". There were nineteen students $(54 \%$ of 35 students) who have "adequate vocabulary, made obvious grammatical mistakes, slight foreign accent". Also, there was two students (6\% of 35 students) who have "good range of vocabulary, occasional grammar slip, slight foreign accent". Meanwhile, no student spoke with wide vocabulary appropriately used, virtually no grammar mistakes.

The score on each student's speaking performance is obtained from the indicators of both fluency and accuracy. The score from both inter-raters is sum up and then multiplied by total indicators (five). From data analysis above, it was known that there were twenty-two students out of 35 students who passed the Minimum Passing Grade. It means that percentage of the students' speaking performance in this cycle was $62 \%$. This means that the first criterion of success in this cycle has not been achieved yet and the research was necessary to continue to cycle 2 .

\section{b. Discussion of the Findings on the Students' Involvement at Cycle 1}

In obtaining the data on the students' involvement in the teaching learning process, observation checklist, field notes were utilized. The observation checklist consisted of four indicators or items which should be done by the students, they 
are: (1) asking questions for clarification frequently; responding to and or answering the teacher's instruction and questions; (3) doing the task(s) by making brief notes actively; and (4) helping and or asking for help from each other. Field notes were used to cover things which were uncovered in the observation checklist.

The observation was done during the implementation of CLT. The criterion determined for the students' involvement was that 100 $\%$ of the students achieve at least the "active enough stage". In this case, the students are considered as active if they do two out of four indicators in the observation checklist. Table 4.2 shows the students' involvement based on the indicators of the observation checklist.

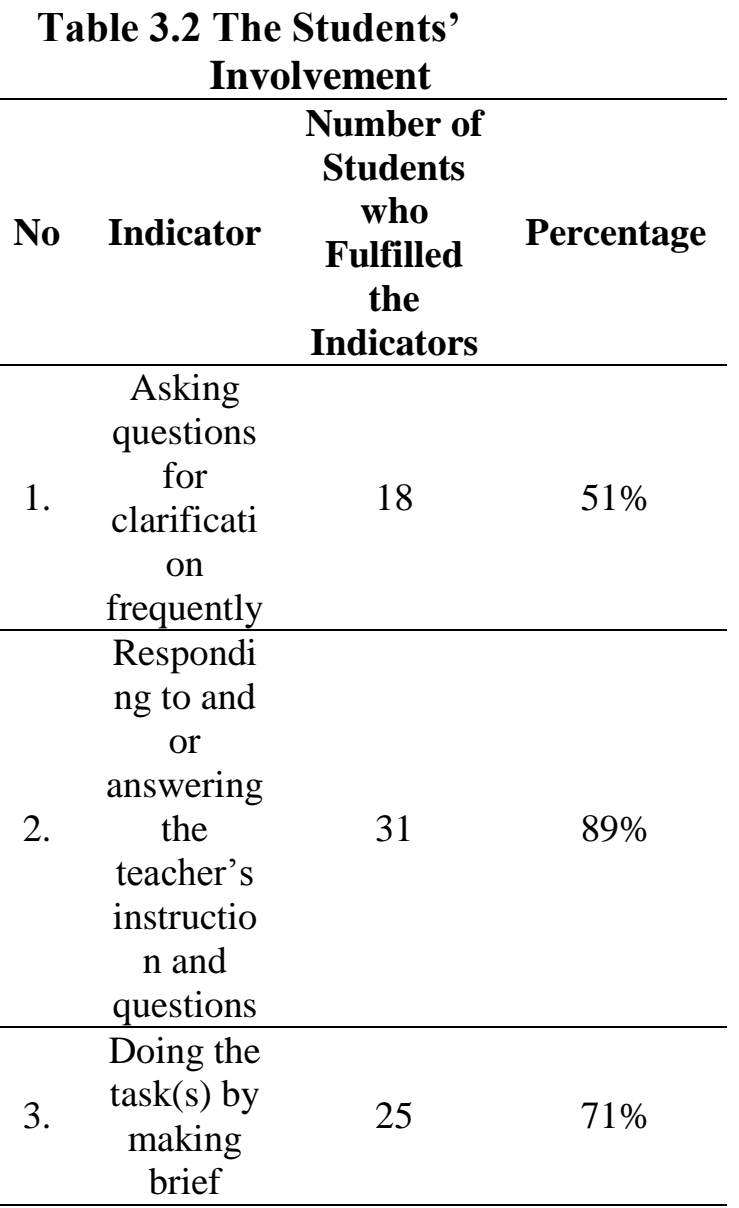

\begin{tabular}{ccc}
\hline \multicolumn{3}{c}{ notes } \\
actively
\end{tabular}

As shown in Table 3.2, the result of the data analysis showed that there were four inactive students (4\% of 35 students). There were twenty students (57\% of 35 students) who were categorized "active enough". There were eleven students ( $31 \%$ of 14 students) that fell into the "active category". And, there was no student ( $0 \%$ of 35 students) that was categorized "very active" student.

Furthermore, in this cycle, there were eighteen students $(51 \%$ of 35 students) that fell into the category of "asking questions for clarification frequently. Thirty-one students ( $89 \%$ of 35 students) were responding to and or answering the teacher's instruction and questions. There were twenty-five students (71 $\%$ of 35 students) who were doing the task(s). Only seventeen students (49\% of the students) were helping and or asking for help from each other.

Field notes revealed some points, general points, good points, and points to improve in the implementation of CLT in the teaching and learning of speaking. In the pre-teaching activity, the teacher explained what was going to be done and all the students could 
easily understand the instruction. This is a general point. In the postteaching, some of the students could do the task(s) well. Also, they were brave to speak louder and did not care when their friends laughed at them. This is a good point. In whilstteaching, the male students played much and sometimes they did not understand the teachers' instruction. This is a point to improve.

To sum up, the result of the data analysis from the two sources of data, especially the observation checklist, indicated that the second criterion of success was not achieved yet. It was not achieved yet since the percentage of the active involvement (active + active enough + very active) in the observation checklist was not $100 \%$. Based on the data above, it showed that the students' involvement in teaching learning process was $88 \%$. That's why the second criterion of success in this research has not been categorized as successful. Therefore, the researcher still needs to continue to the next cycle because both of the criteria of success have not been achieved yet.

\section{c. Discussion of the Findings on the Students' Speaking Performance at Cycle 2}

From the analysis of the students' speaking performance, it was found that there was a significant improvement of the students' speaking performance, although some of them still made mistakes on some language elements being observed.

The same as that in Cycle 1, the researcher used the scoring rubric as the instrument to measure the students' speaking performance or achievement. Meanwhile, the researcher employed observation checklist to achieve the data about students' involvement during the teaching learning process, in addition, questionnaire and field notes were used as supporting data related to those two criteria above.

The score of the students' speaking performance can be seen in the following table

Table 3.3. The Students' Score of Speaking Performance

\begin{tabular}{|c|c|c|c|}
\hline No & $\begin{array}{l}\text { Score } \\
\text { Range }\end{array}$ & $\begin{array}{c}\text { Number } \\
\text { of } \\
\text { Students }\end{array}$ & Percentage \\
\hline 1 & $80-100$ & 9 & $26 \%$ \\
\hline 2 & $75-79$ & 12 & $34 \%$ \\
\hline 3 & $70-74$ & 9 & $26 \%$ \\
\hline 4 & $65-69$ & 0 & $0 \%$ \\
\hline 5 & $<64$ & 5 & $14 \%$ \\
\hline \multicolumn{2}{|c|}{ Total } & 35 & $100 \%$ \\
\hline
\end{tabular}

Based on the data above, it can be seen that nine students ( $26 \%$ of 35 students) achieved the score range of $80-100$. There were twelve students (34\% of 35 students) who achieved the score in the range of $75-79$. There were nine students $(26 \%$ of 35 students) who achieved the score range of $70-74$. There was no student who achieved the score in the range of $65-69$. Meanwhile, there were five students (14\% of 35 students) who achieved the score range in the range of $<64$.

Based on the analysis of the students' speaking performance on cycle 2 , it was found that in term of fluency in this cycle, there was no any student ( $0 \%$ of 35 students) "fell into the category of speechless or do not talk anything". There were nine students (26\% of 35 students) "fell into the category of very hesitant and brief utterances, sometimes difficult to understand". There were twelve students (34\% of 35 students) who 
"fell into the category of got ideas across, but hesitantly and briefly". Then, there were eight students $(23 \%$ of 35 students) who "fell into the category of effective communication in short turn". And there were six students (17\% of 35 students) who fell into the category of have easy and effective communication".

In terms of accuracy, no student was little or no language produced. There were ten students (29\% of 35 students) was "poor vocabulary, mistakes in basic grammar, may have very strong foreign accent". There were eleven students (31\% of 35 students) were "adequate vocabulary, make obvious grammatical mistakes, slight foreign accent". Then, there were seven students (20\% of 35 students) had "good range of vocabulary, occasional grammar slip, slight foreign accent". There were seven students (20\% of 35 students) "spoke with wide vocabulary appropriately used, virtually no grammar mistakes".

\section{d. Discussion of the Findings on the Students' Involvement at Cycle 2}

In obtaining the data on the students' involvement in the teaching learning process, observation checklist, field notes were utilized. The observation checklist consisted of four indicators or items which should be done by the students, they are: (1) asking questions for clarification frequently;

responding to and or answering the teacher's instruction and questions; (3) doing the task(s) by making brief notes actively; and (4) helping and or asking for help from each other. Field notes were used to cover things which were uncovered in the observation checklist.

The observation was done during the implementation of CLT. The criterion determined for the students' involvement was that 100 $\%$ of the students achieve at least the "active enough stage". In this case, the students are considered as active if they do two out of four indicators in the observation checklist. Table 4.2 shows the students' involvement based on the indicators of the observation checklist.

\begin{tabular}{|c|c|c|c|}
\hline & $\begin{array}{l}3.4 \\
\text { Involv }\end{array}$ & $\begin{array}{l}\text { The } \\
\text { ment }\end{array}$ & its' \\
\hline No & Indicator & $\begin{array}{c}\text { Number of } \\
\text { Students who } \\
\text { Fulfilled the } \\
\text { Indicators } \\
\end{array}$ & Percentage \\
\hline 1. & $\begin{array}{l}\text { Asking } \\
\text { questions for } \\
\text { clarification } \\
\text { frequently }\end{array}$ & 18 & $51 \%$ \\
\hline 2. & $\begin{array}{l}\text { Responding } \\
\text { to and or } \\
\text { answering } \\
\text { the teacher's } \\
\text { instruction } \\
\text { and } \\
\text { questions }\end{array}$ & 33 & $94 \%$ \\
\hline 3. & $\begin{array}{l}\text { Doing the } \\
\operatorname{task}(\mathrm{s}) \text { by } \\
\text { making brief } \\
\text { notes } \\
\text { actively }\end{array}$ & 35 & $100 \%$ \\
\hline 4. & $\begin{array}{l}\text { Helping or } \\
\text { and asking } \\
\text { for help from } \\
\text { each other }\end{array}$ & 13 & $37 \%$ \\
\hline
\end{tabular}

As shown in Table 3.4, the 
result of the data analysis showed that there was none inactive student (0\% of 35 students). There were twenty-three students $(66 \%$ of 35 students) who were categorized "active enough". There were ten students (29\% of 35 students) that fell into the "active category". And, there were two students (6\% of 35 students) that were categorized "very active" student.

Furthermore, in this cycle, there were eighteen students $(51 \%$ of 35 students) that fell into the category of "asking questions for clarification frequently. Thirty-three students (94\% of 35 students) were responding to and or answering the teacher's instruction and questions. There were thirty-five students (100\% of 35 students) who were doing the task(s). Only thirteen students (37\% of the 35 students) were helping and or asking for help from each other.

Field notes revealed some points, general points, good points, and points to improve in the implementation of CLT in the teaching and learning of speaking. In the pre-teaching activity, the teacher explained what was going to be done and all the students could easily understand the instruction, the students pay attention to the teacher's explanation. This is a general point. In the whilst teaching, the students were enthusiastic in accomplishing the task (s). This is a good point. Some students complain to create the monologue many times. This is point to improve.

Based on the data above, it was known that the percentage of the active involvement (active + active enough + very active) in the observation checklist was $100 \%$.
Since the criteria on both aspects have been fulfilled, so the cycle is stopped.

To sum up, we could see that most of students were interested in learning English speaking through CLT. They selves-confidence to express their ideas in speaking activity inside classroom, most of them could minimize their fears and shy to speak, the frequency and percentage of students' speaking skill were increased well in each cycles. In addition, CLT could motivate the students to be active and had a great participation in speaking activity during teaching and learning process in classroom. Since the classroom is a community where learners learn through collaboration and sharing. Furthermore, effective classroom learning tasks and exercises provide opportunities for students to negotiate meaning, expand their language resources, notice how language is used, and take part in meaningful intrapersonal exchange (Richrads, 2006, p. 20). Furthermore, he explains that second language learning is facilitated when learners are engaged in interaction and meaningful communication.

Another aspect found by the researcher is that CLT motivate students and minimize students' problems in speaking English such as: low motivation to speak, don not have enough vocabularies to express their ideas, feeling shy when they spoke in front of their friends, still get rigid to express their ideas through oral communication, and most problem faced before until there is no student who was inactive in speaking anymore. 


\section{Closing}

a. Summary

Speaking is a productive skill that involves using speech to express meaning to other people. Speaking is also known as speech or utterances with the purpose of having intention to be recognized by speaker and the receiver processes the statements in order to recognize their intentions. It is depending on the complexity of the information to be communicated; however, the speaker sometimes finds it difficult to clarify what they want to say. This is particularly true in higher school level.

In fact, as fellow students who had learned English intensively, the students should be able to interact orally each other through English. It is because of the following: the lack of practice of the language both inside and outside the classroom is the main cause of the students' failure in mastering speaking skill; Besides, the very limited time is also considered to support the failure of the students' speaking skill since the English lesson at the higher school is usually held just for two hours per week; higher schools apply the integrated teaching of English consisting of listening, speaking, reading, and writing. Consequently, the proportion of teaching speaking is very limited because it is integrated with the other three language skills. Since the time for teaching speaking is very limited, English lecturer are expected to be able to make use the available time more effectively and efficiently by applying a certain strategy that can involve all students more actively in joining the speaking class; furthermore, most of the students were not really motivated in speaking task. Some of them really wanted to express their ideas or feeling about the material being taught, but they do not know how to express their idea. This was due their limited vocabulary and the classroom encouragement (friends and different cultural background); Some of them knew how to construct sentences but they were reluctant to speak; They were afraid of making mistakes in pronouncing the words or English grammar; Besides, they were afraid of being laughed at by other students, so they just keep silent and bore their ideas and feeling in their mind; In addition, speaking practice is more difficult than sitting back and listening to the teacher or wandering off into some dream world.

Considering the problem above, then the researcher try to implement CLT to improve students' speaking skill.

As the result, most of students were interested in learning speaking through CLT. They selvesconfidence to express their ideas in speaking activity inside classroom, most of them could minimize their fears and shy to speak, the frequency and percentage of students' speaking skill were increased well in each cycles. In addition, CLT could motivate the students to be active and had a great participation in speaking activity during teaching and learning process in classroom. Since the classroom is a community where learners learn through collaboration and sharing. Furthermore, effective classroom learning tasks and exercises provide opportunities for students to negotiate meaning, expand their language resources, notice how language is used, and take part in meaningful intrapersonal exchange 


\section{b. Suggestion}

Regarding this condition, teachers/lecturers can use CLT as the appropriate approach that hopefully can overcome the problem listed and improve the students' speaking skill. It is because learning activities in CLT focuses on real oral communication with variety of language without too focus on form of grammatical patterns. Furthermore, classroom activities are often designed to focus on completing tasks that are mediated through language or involve negotiation of information and information sharing. It enables students to be more comfortable, because the content is closely related to their real world that it will decrease their anxiety in making such failure and/or mistakes.

For the case of time, the researcher suggests that the higher school provides English subject per semester as local subject. By this way, students can get special treatment regarding to English skills that previously taught in integrated way. When fellow students get a specific class (un-integrated), they will get more time to learn about every skill in English.

\section{References}

Brown, Gillian \& Yule, George. (1999). Teaching the spoken Language. New York: Cambridge University Press

Burns, A. \& Joice, H. (1993). Focus on Speaking ( $2^{\text {nd }}$ edition). Sydney: Macquarie University.

Efrizal, Dedi. (2012). Improving Students' Speaking through Communicative Language Teaching Method at Mts Jaalhaq, Sentot Ali Basa Islamic Boarding School of Bengkulu. International Journal of
Humanities and Social Science Vol. 2 No. 20

Harmer, Jeremy. (2007). The Practice of English Language Teaching, $\quad\left(4^{\text {th }} \quad\right.$ Edition). London: Pearson Longman.

Harmer, Jeremy. (1998). How to teach English: an introduction to the practice of English language teaching. New York: Longman

Jones, L. (2007). The StudentCentered Classroom. New York: Cambridge University Press.

Kayi, H. (2006). Teaching Speaking: Activities to promote Speaking in a Second Language. (Online),TESL Journal, Vol XII, No.11.

Kemmis,S. \& Mc.Taggart, R. (1988). The Action Research Planner. Gee Long: Deaken University Press.

Latief, M.A. (2008). Penelitian Tindakan Kelas Pembelajaran Bahasa Inggris. Malang: Universitas Negeri Malang.

Lan, L.S. (1994). Fluency and Accuracy in Spoken English Implication for Classroom Practice in Bilingual Context.(Online )http// www.melta .org.my/ET/1994main4.html. Accessed on $27^{\text {th }}$ of December, 2010.

Lightbown, P.M \& Spada, N. (2001). How Languages are Learned ( $2^{\text {nd }}$ Edition). New York: Oxford University Press.

Littlewood, W. (1981). Communicative Language Teaching. Cambridge: Cambridge University Press Lucantoni, P. (2002). Teaching and Assessing Skills in English as a Second Language. Cambridge: 
Cambridge University Press.

Nambiar, S.A. (1985). Suffer the Students to Speak. A Periodical for Classroom Language

Teachers.Vol.7,No.2: 44-57.

Richard, Jack C. (2006). Communicative Language Teaching Today. New York: Cambridge University Press.

Richard, Jack C. \& Renandya W.A. (2002). Methodology in language Teaching: An Anthology of Current Practice. Cambridge: Cambridge University Press.

Richards, Jack C \& Theodore Rodgers (2001). Approaches and Methods in Language teaching. Second Edition. New York: Cambridge University Press.

Richards, Jack C \& Theodore Rodgers. (1999). Approaches and Method in Language Teaching: Communicative Language Teaching. New York: Cambridge University Press.

Richards, Jack C \& Theodore Rodgers (1985). The secret life of methods. In Richards, The Context of Language Teaching, pp. 32-45. Cambridge: Cambridge University Press.

Rickheit, Gert \& Strohner, Hans (2008). Handbook of Communication Competence. Berlin: Mouten de Gruyter.

Spratt, M., Pulverness, A. \& Williams, M. (2005). The TKT (Teaching Knowledge Test) Course, United Kingdom: Cambridge University Press.

Wenjie, Cai. (2009). Using Communicative Language Teaching (CLT) to Improve Speaking Ability of Chinese
Non-English Major Students. University of WisconsinPlatteville 